\title{
Wernicke encephalopathy in a patient with Burkitt lymphoma with typical and atypical findings on MRI
}

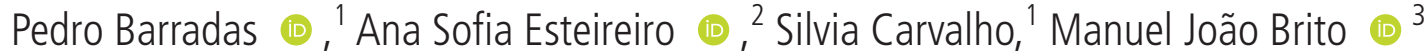

${ }^{1}$ Neuroradiology, Centro Hospitalar e Universitário de Coimbra EPE, Coimbra, Coimbra, Portugal

${ }^{2}$ Paedeatrics, Centro Hospitalar do Oeste Unidade de Caldas da Rainha, Caldas da Rainha, Portugal

${ }^{3}$ Pedeatric Oncology, Centro Hospitalar e Universitario de Coimbra EPE Hospital Pediátrico de Coimbra, Coimbra, Coimbra, Portugal

\section{Correspondence to} Dr Ana Sofia Esteireiro; esteireira@gmail.com

Accepted 2 January 2021

\section{DESCRIPTION}

Characterised by ocular, consciousness and gait alterations, Wernicke encephalopathy (WE) is an acute neurological pathology due to vitamin $\mathrm{B}_{1}$ (thiamine) deficiency. Often associated with alcohol consumption, thiamine deficiency leading to WE can also occur in non-alcoholic (NA) patients and result from prolonged vomiting, systemic infections and chemotherapy. ${ }^{1-3}$ Given WE's potential morbidity and mortality, early diagnosis and treatment are imperative. Unfortunately, it is often underdiagnosed, especially in the paediatric age, where NA causes are more frequent. ${ }^{3}$

MRI in WE can show symmetric signal change alterations typically involving the medial thalami, mammillary bodies, tectal plate and periaqueductal area. There are also atypical MRI findings, found more frequently in NA patients, with involvement of the cerebellum, cranial nerve nuclei, red nuclei, caudate nuclei, splenium and cerebral cortex. ${ }^{1-3}$

A 16-year-old boy diagnosed with a stage IV Burkitt lymphoma (cerebrospinal fluid and marrow involvement), under treatment according to international indications from Protocol: Inter-B-NHL ritux 2010 and in complete remission after induction therapy, reporting recent weight loss, approximately $29 \mathrm{~kg}$ since the diagnosis 2 months earlier ( $24 \%$ of his body weight), was admitted to undergo a cycle of chemotherapy with rituximab, high-dose cytarabine and etoposide. At the third day of treatment, he suffered nausea, anorexia and apathy.

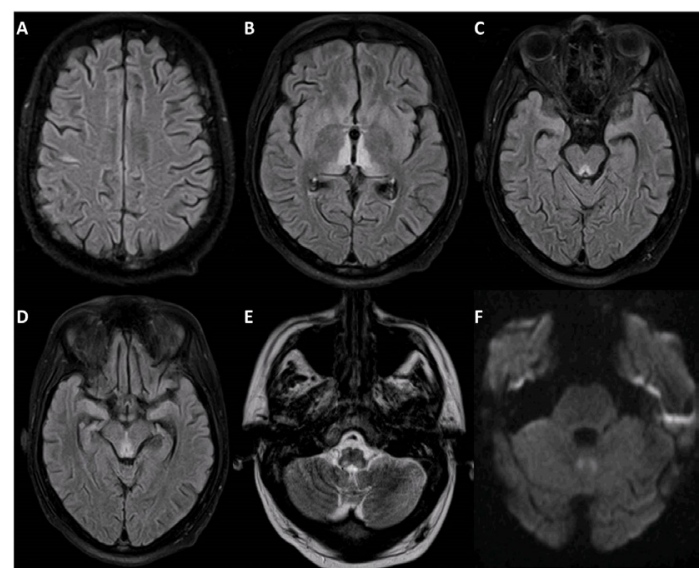

Limited 2021. No commercial re-use. See rights and permissions. Published by BMJ.

To cite: Barradas $P_{\text {, }}$
Esteireiro AS, Carvalho S,
et al. BMJ Case Rep
2021;14:e239392.
doi:10.1136/bcr-2020-
239392

Figure 1 Axial FLAIR (A-D), T2 (E) and diffusionweighted imaging $(F)$ images showing multiple periphery of the third ventricle, tectal plate and the periaqueductal grey matter. Abnormal signal intensity can also be seen in the frontal lobe cortex, medulla and vermis. FLAIR, FLluid-Attenuated Inversion Recovery. hyperintense lesions involving the medial thalami,

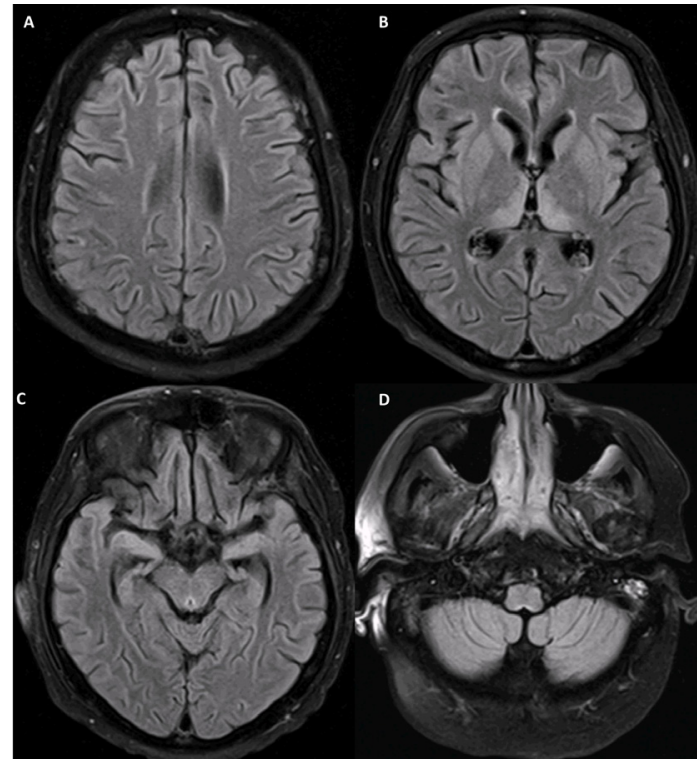

Figure 2 Axial FLAIR (A-D) images of follow-up MRI showing significant regression of the lesions after 5 days of thiamine. FLAIR, FLuid-Attenuated Inversion Recover.

After the fourth day and final day of treatment, he showed no signs of improvement and had pancytopenia requiring transfusion support. ${ }^{4}$ Over the next 10 days, his clinical status deteriorated, as he exhibited fluctuations in consciousness, fever and altered speech, later needing intubation. Lumbar puncture and CT of the head were conducted but showed no significant changes, other than mild brain atrophy, which was attributed to corticotherapy. Still, the clinical picture suggested Posterior Reversible Encephalopathy Syndrome (PRES), sometimes associated with the treatment, in particular highdose cytarabine. ${ }^{5}$

However, subsequent MRI of the brain showed multiple T2 hyperintense lesions involving the medial thalami, periphery of the third ventricle, tectal plate and the periaqueductal grey matter, suggesting the diagnosis of WE. Additionally, abnormal signal intensity was seen in the frontal lobe cortex, medulla and vermis, the vermian lesions being more evident on diffusion-weighted imaging (figure 1). No enhancement was shown after gadolinium.

The patient was then started on intravenous thiamine in a daily high-dose protocol $(500 \mathrm{mg} / 8$ hours). ${ }^{6}$ The treatment was administered for 10 days, with radiological improvement on follow-up MRI on the sixth day, which showed significant regression of all lesions (figure 2). Clinical improvement was seen after the 10th day and final day of 
thiamine, with the patient being discharged 5 days later, still showing periodic confusion and marked weakness, especially in the lower limbs.

Oncologic patients have several risk factors that can predispose to WE, whether it be decreased intake of thiamine due to anorexia, reduced absorption due to vomiting, increased expenditure in a hypermetabolic state (eg, rapidly growing tumours such as haematological malignancies, infections and steroid use) or inactivation by chemotherapy. ${ }^{1}$

However, many of these same risk factors predispose to other neurologic pathologies hindering the diagnostic process. One study involving 1000 patients that underwent hematopoietic stem cell transplantation revealed $31 \%$ suffered from neurologic complications, one of the rarer (1\%) but more serious ones being WE. ${ }^{78}$

Rituximab has been associated with progressive multifocal leucoencephalopathy, and high-dose cytarabine use can be a risk factor for PRES. ${ }^{59}$ Still, both of these hypotheses were discarded given the clinical and imagiological evolution.

The diagnosis of WE is complex, depending on clinical, laboratory and imaging findings. Ocular, cerebellar and consciousness alterations constitute the clinical triad often associated with this disease, but it is rarely reported. Direct measurements of thiamine can help confirm the diagnosis but do not exclude it (eg, mutations of thiamine transporter genes). MRI findings have relatively low sensitivity $(53 \%)$, but are highly specific $(93 \%)$, in the diagnosis. ${ }^{10}$

In this case, the MRI findings suggested the diagnosis of WE, which can be missed in NA patients, namely, in patients with cancer.

\section{Learning points}

- Wernicke encephalopathy (WE) is an acute neurologic disease resulting from thiamine deficiency, often underrecognised, particularly in the paediatric age, and with severe consequences if not treated early.

- Despite often being a clinical diagnosis, MRI can be a useful tool in revealing WE-associated lesions and in excluding differential diagnosis.

- MRI in patients with WE can show lesions in typical and atypical locations, the latter being often associated with nonalcoholic patients.
This case also highlights the occurrence of atypical locations for the disease, such as the cerebellum and cerebral cortex, in the group of NA patients. ${ }^{2}$

Contributors MJB was personally involved with the care of the patient described in this case report, discussed the case with SC and PB (neuroradiologists), who helped with the construct of this case report, and reviewing several drafts, including relevant radiological figures. ASE was also involved in background research and manuscript writing.

Funding The authors have not declared a specific grant for this research from any funding agency in the public, commercial or not-for-profit sectors.

Competing interests None declared.

Patient consent for publication Parental/guardian consent obtained.

Provenance and peer review Not commissioned; externally peer reviewed.

\section{ORCID iDs}

Pedro Barradas http://orcid.org/0000-0002-1693-5770

Ana Sofia Esteireiro http://orcid.org/0000-0003-1603-0602

Manuel João Brito http://orcid.org/0000-0001-8878-840X

\section{REFERENCES}

1 Isenberg-Grzeda E, Rahane S, DeRosa AP, et al. Wernicke-Korsakoff syndrome in patients with cancer: a systematic review. Lancet Oncol 2016;17:e142-8.

2 Zuccoli G, Santa Cruz D, Bertolini M, et al. Mr imaging findings in 56 patients with Wernicke encephalopathy: nonalcoholics may differ from alcoholics. AJNR Am J Neuroradiol 2009;30:171-6.

3 Cefalo MG, De loris MA, Cacchione A, et al. Wernicke encephalopathy in pediatric neuro-oncology: presentation of 2 cases and review of literature. I Child Neurol 2014;29:NP181-5.

4 Minard-Colin V, Auperin A, Pillon M, et al. Results of the randomized intergroup trial Inter-B-NHL Ritux 2010 for children and adolescents with high-risk B-cell non-Hodgkin lymphoma (B-NHL) and mature acute leukemia (B-AL): evaluation of rituximab (R) efficacy in addition to standard LMB chemotherapy (CT) regimen. JCO 2016;34:10507

5 Tam CS, Galanos J, Seymour JF, et al. Reversible posterior leukoencephalopathy syndrome complicating cytotoxic chemotherapy for hematologic malignancies. Am J Hematol 2004;77:72-6.

6 Nishimoto A, Usery J, Winton JC, et al. High-Dose parenteral thiamine in treatment of Wernicke's encephalopathy: case series and review of the literature. In Vivo 2017:31:121-4.

7 Teive HAG, Funke V, Bitencourt MA, et al. Neurological complications of hematopoietic stem cell transplantation (HSCT): a retrospective study in a HSCT center in Brazil. Arq Neuropsiquiatr 2008;66:685-90.

8 Server A, Bargalló N, Fløisand Y, et al. Imaging spectrum of central nervous system complications of hematopoietic stem cell and solid organ transplantation. Neuroradiology 2017;59:105-26.

9 Berger JR, Malik V, Lacey S, et al. Progressive multifocal leukoencephalopathy in rituximab-treated rheumatic diseases: a rare event. J Neurovirol 2018;24:323-31.

10 Galvin R, Bråthen G, Ivashynka A, et al. EFNS guidelines for diagnosis, therapy and prevention of Wernicke encephalopathy. Eur J Neurol 2010;17:1408-18.

Copyright 2021 BMJ Publishing Group. All rights reserved. For permission to reuse any of this content visit

https://www.bmj.com/company/products-services/rights-and-licensing/permissions/

BMJ Case Report Fellows may re-use this article for personal use and teaching without any further permission.

Become a Fellow of BMJ Case Reports today and you can:

- Submit as many cases as you like

- Enjoy fast sympathetic peer review and rapid publication of accepted articles

- Access all the published articles

- Re-use any of the published material for personal use and teaching without further permission

Customer Service

If you have any further queries about your subscription, please contact our customer services team on +44 (0) 2071111105 or via email at support@bmj.com.

Visit casereports.bmj.com for more articles like this and to become a Fellow 